\title{
SIMULATION ASSEMBLY IN TEACHING
}

\section{Štefan VACLAV-Martin BENOVIČ}

\begin{abstract}
This paper discuss about the simulation, her purpose, meaning, principles and uses in practice and teaching. The paper deals with next topics: general tasks of simulation, investigation of today's theory and practice condition, acquaint oneself with simulation's progressing, reasons for simulation's using, simulation employ to design, development, mounting and manufacturing systems for operating and uses of virtual reality in simulation. This contribution contains a focus of current simulation software used in assembly and manufacturing systems. In this focus are characterized main figures, areas of use, interface and description of general functions.
\end{abstract}

Key words: simulation, assembly, simulation software, teaching.

\section{SIMULÁCIA MONTÁŽE VOVÝUČBE}

Resumé: Tento príspevok pojednáva o simulácii, jej zmysle, význame, princípoch, využití v praxi a výučbe. V príspevku sú prebrané nasledovné témy: hlavné úlohy simulácie, prieskum súčasného stavu teórie a praxe simulácie, oboznámenie sa s rozvojom simulácie, dôvody pre použivanie simulácie, využitie simulácie pri návrhu, vývoji, prevádzke montážnych i výrobných systémov a využití virtuálnej reality $v$ simulácii.

Vpráci je uvedený prehl'ad simulačného software použivaného v súčasnej dobe v montážnych a výrobných systémoch. V uvedenom prehl'ade sú charakterizované hlavné znaky, oblasti využitia, rozhrania a popis základných funkcií.

Kličcová slova: simulácia, montáž, simulačný softvér, výučba.

1

Úvod

Súčasný trh núti podniky znižovat' náklady a zrýchl'ovat' nábeh výrobkov do výroby. Riešením je iba riadená paralelná spolupráca vývoja a technickej podpory výroby. Takú spoluprácu zabezpečujú systémy PLM (product lifecycle management), ktoré umožnia paralelné zdiel'anie informácií, simuláciu a optimalizáciu výrobných zariadení a procesov pred ich fyzickým prevedením. Úspech podniku závisí na rade faktorov. V prvom rade je to efektívnost' výroby, tzn. ako podnik dokáže $\mathrm{s}$ nízkymi nákladmi vyrábat'. Už dávno bolo odzvonené starým metódam vývoja, kedy sa tajomní páni v bielych plášt’och zaoberali roky vývojom niečoho, často nezávisle na trhu, vlastnej technológii a výrobe tzv. "strategy of hope". Dnes je úspešné zavedenie nového výrobku doslova životným záujmom celého podniku. $Z$ pohl'adu realizácie je to multidisciplinárna záležitost', zovretá tvrdými kritériami trhu, peňazí a času. To znamená, že nový výrobok je treba zaviest' rýchle a $\mathrm{s}$ minimálnymi nákladmi, respektíve s nákladmi, ktoré sa v predpokladanej dobe vrátia. Toho sa dá dosiahnut' iba paralelným vývojom a simuláciou výroby výrobku vo virtuálnom prostredí ešte pred výrobou fyzických prototypov a fyzickou prípravou výrobku. Ušetrí sa tým mnoho zmien, materiálu a času a l’udskej energie. Simulácia našla využitie aj v oblastiach, ako sú napríklad kozmické lety, vojenské a vojnové operácie, urbanistické systémy, počítačové systémy, logistické a výrobné systémy, podnikatel'ské hry, finančné modely, ekonometrické modely, ekológia a ochrana životného prostredia, vývoj spoločnosti, biovedy a pod.

Z úvodu je zrejmá potreba reagovat' na dané potreby výučbou uvedených systémov.

Zvládnutie výučby je podmienkou budúcich absolventov na úspešné zaradenie sa do praxe [8]. Problémami výučby montáže na vysokej škole technického zamerania sa zaoberajú autori prác $[5,6,7]$.

\section{Význam a zmysel simulácie}

Simulácia je experimentálna metóda $\mathrm{v}$ ktorej nahrádzame reálny systém počítačovým modelom. Na takomto modeli je možné vykonat' množstvo experimentov, vyhodnotit' ich popr. optimalizovat' a výsledky aplikovat' na reálny systém. Neexistuje iná "metóda" alebo "teória", ktorá by umožňovala experimentovat' so zložitým 
systémom ešte predtým ako bol uvedený do prevádzky. Neexistuje iný algoritmus, ktorý by umožňoval za niekol'ko minút "prehrat" na počítači zložité procesy, ktoré reálne trvajú rádovo týždne alebo mesiace. Je to ideálny nástroj pre podporu rozhodovania na rozličných úrovniach v podniku.

Dôvodom pre používanie simulácie je, že analytické metódy (teória hromadnej obsluhy, obslužné siete, lineárne programovanie a i.) majú obmedzené použitie pri riešení praktických problémov.

Vznikajú nové požiadavky na pružnost' v celej podnikovej organizačnej štruktúre, nové decentralizované, modulárne organizačné jednotky a nové organizácie práce (tímová práca, simultánne inžinierstvo).

Jedným $z$ d'alších dôvodov nasadenia simulácie je aj humanizácia pracovísk. Najmä vo vel'kých výrobných a montážnych podnikoch sa často zabúda na tých l'udí ktorí sa na výrobe a montáži produktu priamo podiel'ajú, a ktorí môžu v najväčšej miere ovplyvnit' kvalitu produktu a tým nepriamo aj jeho úspech na trhu. Často je prostredie na výrobných a montážnych pracoviskách nevyhovujúce mnohokrát za hranicou tolerancie zákona (práca nad hlavou, v stiesnených podmienkach, obrovskom časovom strese, v neprimeranom hluku a pri vysokých teplotách).

Simulácia v súčasnosti patrí medzi klúčové techniky priemyslového inžinierstva.

Z rozvoja simulácie profitujú nielen vel'ké automobilky a iné priemyslové koncerny, ale aj ich subdodávatelia, ktorí sú stále viac zapojení do dodávatel'ských ret’azcov a tokov výmeny informácií, ktoré sa týkajú i vývoja nových produktov. Využitie zdiel’aných simulačných modelov u automobilov napríklad umožňuje dodávatel'ovi virtuálne zabudovat' nový diel do vozu a simulovat' jeho činnost' priamo v modeli automobilu. To napomáha včasnému odhaleniu závad, a tiež to skracuje dobu potrebnú na vývoj nových typov vozidiel. Vyspelé firmy dnes zavádzajú a použivajú tento prístup, pretože je rýchlejší a lacnejší a stal sa význačným konkurenčným faktorom. Napríklad v automobilovom priemysle je známy silný konkurenční boj medzi výrobcami z Japonska, USA a Európy. Čas prípravy nového typu bol skrátený z 36 mesiacov na 24 a niektoré projekty bežia už v cykle 18 mesiacov.

Jeden $z$ najviac sa rozvíjajúcich oborov modernej automatizácie je spracovanie obrazu. Naplno sa to prejavilo $\mathrm{v}$ automobilovom priemysle. Teraz je na rade obalový priemysel, logistika, ale tiež montáž a kontrola povrchov vyrobených dielov.

Jednou zo špičkových aplikácií automatizácie v strojárenskej výrobe je výroba dielcov $\mathrm{v}$ automobilke BMW v Dingolfinu. Je tu uplatnené centrálne riadenie a vizualizácia v kombinácii s inteligentnými decentralizovaným i modulmi snímačov a akčných členov. Svoje miesto tu pritom vedl'a digitálnych zberníc a riadiacich modulov našli i tradičné programovatel'né automaty [1].

Mimoriadne pružné riešenie pre montážne práce predviedla firma MA z Freiburgu [2]. Jeho hybridná základná štruktúra sa skladá z modulov - manuálnych pracovísk, transportných liniek a automatických staníc. Moduly môžu byt' jednoducho zostavené do akejkol’vek zákaznícky špecifickej montážnej linky. Podmienkou sú jasne a štandardne definované rozhrania medzi modulmi. Montáž a uvedenie do prevádzky sú potom vel'mi jednoduché a rýchle.

Pružnost' automatizačných štruktúr je v prvej fáze riešení často spojená s vysokými nákladmi. Opakované zmeny výrobného sortimentu a skracujúce sa inovačné cykly však spôsobujú to, že iná než pružná automatizácia nie je myslitel'ná.

$\mathrm{Na}$ základe informácií o realizovaných projektoch a štúdiách na báze simulácie a virtuálnej reality v koncerne Volkswagen je možné badat' rastúci počet aplikácií VR v rôznych oblastiach. Podl'a [3] bolo v roku 2004 realizovaných 33 štúdií na báze VR, ktorých rozdelenie podl'a jednotlivých značiek koncernu je na obr. 4.

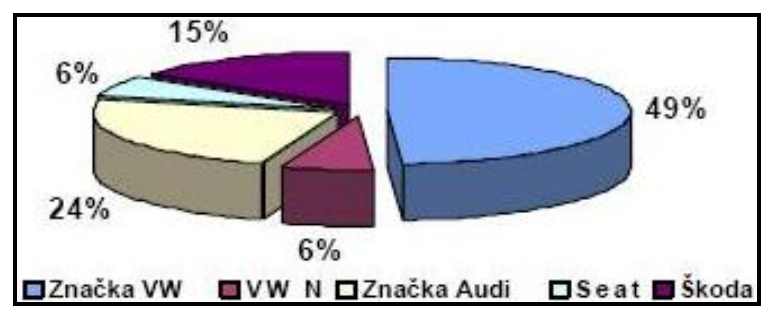

Obr 1: Stav VR v koncerne Volkswagen

\section{Simulácia v praxi}

V tejto kapitole sú prehl'adne uvedené simulačné projekty, ktoré boli riešené $\mathrm{v}$ priemysle doma i $\mathrm{v}$ zahraničí, riešené úlohy a dosiahnuté úspory. Vo svete:

GEILINGER: 1. Inštalácia dopravníkového systému. Efekt: Bol analyzovaný projektovaný systém v hodnote 2.6 milióna USD. Vybudoval sa systém v hodnote 1.8 USD, ktorého návratnost' 
bola 6 rokov 2. Optimalizácia distribučného centra $\mathrm{v}$ celkovej hodnote $>60$ mil.USD. Efekt: Niekol'ko stotisíc USD, vyššia spol'ahlivost', zlepšená komunikácia, objektívne rozhodnutia.

LINDE: Projekt montáže s vozíkmi. Výsledok: 54 vozíkov namiesto plánovaných 80 . Náklady: 20 tis. USD, Prínos: 100 tis. USD.

IBM: Optimalizácia kapacity výrobnej linky, dopravného systému (AGV), zásob a rozpracovanej výroby Výsledok: 3 vozíky (využitie 97\%) namiesto 4 vozíkov (využitie 73 \%). Úspora 40 tis. USD. Prínosy: 310 tis. USD úspory na zásobách.

IPA: 1. Systém riadenia kvality optimalizácia rozvrhovania. Náklady: 35 tis. USD. Úspory: 350 tis. USD 2. Nové riadiace stratégie pre indukčne vedené vozíky (AGVs). Optimalizácia: 23 namiesto 26 vozíkov. Náklady: 35 tis. USD, Úspory: 260 tis. USD.

Mercedes Benz: 1. Optimalizácia dopravy (AGV): 2 usporené vozíky. Náklady: 30 tis. USD, Prínosy: 300 tis. USD. 2. Montáž automobilov: Úspora 1 sekvenčný zásobník. Náklady: 50 tis. USD, Prínosy: 1.000 tis. USD.

Peguform: Just-in-time montáž nárazníkov. Úspory vozíkov a zásobníkov. Náklady: 60 tis. USD, Úspory: > 1.000 tis. USD.

Projekty simulácie realizované $\mathrm{V}$ praxi (Slovensko):

Frič Žilina: Výroba kancelárskych stoličiek redukcia plôch o $322 \mathrm{~m} 2$, redukcia dopravných vzdialeností z 83 na $59 \mathrm{~m}$, redukcia zásob, zvýšenie výkonu bez dodatočných investícií.

SEZ Dolný Kubín: Výroba elektrických zásuviek - zníženie dopravnej intenzity z 506480 na 66060 ( $\mathrm{m}$ x paleta / 3 mesiace), redukcia plôch z $267 \mathrm{~m}$ na $84 \mathrm{~m}$. Zníženie počtu paliet vo výrobe zo 400 na 24, zníženie počtu montážnych pracovníkov z 50 na 24.

AVC Čadca: Výroba prevodoviek Peugeot, Citroën.

Prínosy vyplývajúce z použitia simulácii [9]:

VDI 3633 - nemecká norma pre simuláciu: 2-4 \% - úspory z investovanej sumy. 0.5-1\% náklady na simuláciu.

Fraunhoferov inštitút SRN: Pomer prínosy /náklady > 6:1-informácie od aktívnych používatel'ov simulácie.

Mercedes Benz: Úspory 30 miliónov dolárov a náklady 4 milióny dolárov $\mathrm{v}$ troch rokoch.

Prof. Dr. Ing. Feldmann: $15-20 \%$ rast produktivity existujúcich systémov. $20 \%$ redukcia investícií do nových systémov. 20-60\% redukcia priebežných časov a zásob.

\section{Simulačný software}

V súčasnosti existuje na trhu pomerne široká škála simulačných prostriedkov.

Ceny takýchto systémov sa pohybujú, v závislosti od počítačovej platformy, výkonnosti a rozsahu použitia, od 2000 do 200000 \$.

Ročné náklady na simuláciu $\mathrm{s}$ využitím systému výkonnejšej kategórie, odhaduje firma AESOP GmbH Stuttgart v podmienkach SRN na 200 tisíc DM, pričom cca $80 \%$ z tejto čiastky tvoria mzdové náklady.

I pri týchto vysokých čiastkach treba poznamenat', že v prevažnej väčšine simulačných projektov boli náklady na simuláciu vysoko prevýšené prínosmi.

Najrozšírenejšími aplikáciami na súčasnom trhu so simulačným software sú :

- WITNESS figure. 2 od firmy Lanner,

- EM - Plant od firmy Tecnomatix $\mathrm{GmbH}$,

- Quest.

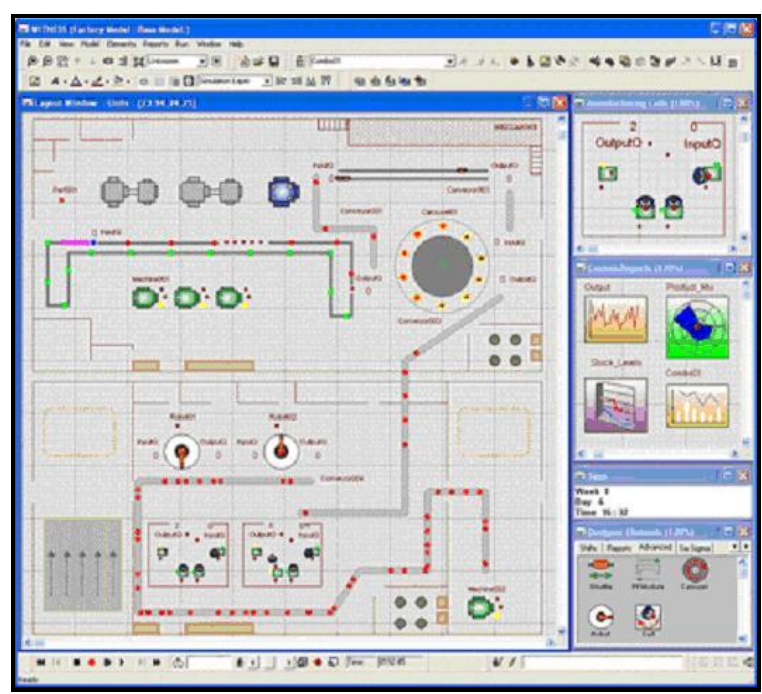

Obr 2: Pohl'ad na uživatel'ské rozhranie programu WITNESS

WITNESS je jednoducho ovládatel'ný a l'ahko osvojitel'ný simulačný program. WITNESS je špecializovaný na vyobrazenie diskrétneho výrobného procesu, ponúka však tiež prvky $\mathrm{k}$ modelovaniu plynulých priebehov. $\mathrm{K}$ dispozícii má vel'ké množstvo prvkov na modelovanie.

WITNESS, je celosvetovo vedúci simulačný systém umožňujúci realite podobné vyobrazenie pracovného prostredia. Cez simulačný model sa dajú dobre pochopit' aj vel'mi zložité procesy. Početné d'alekosiahle dôsledky strategických rozhodnutí a $\mathrm{s}$ tým spojené finančné riziká sú redukované na minimum. To znamená, že existuje istota najlepšieho riešenia pri každom rozhodnutí skôr, ako vzniknú finančné záväzky. 
Software eM-Plant, obr. 3 je štandardný software pre objektovo orientované, grafické a integrované modelovanie, simuláciu a animáciu systémov a procesov.

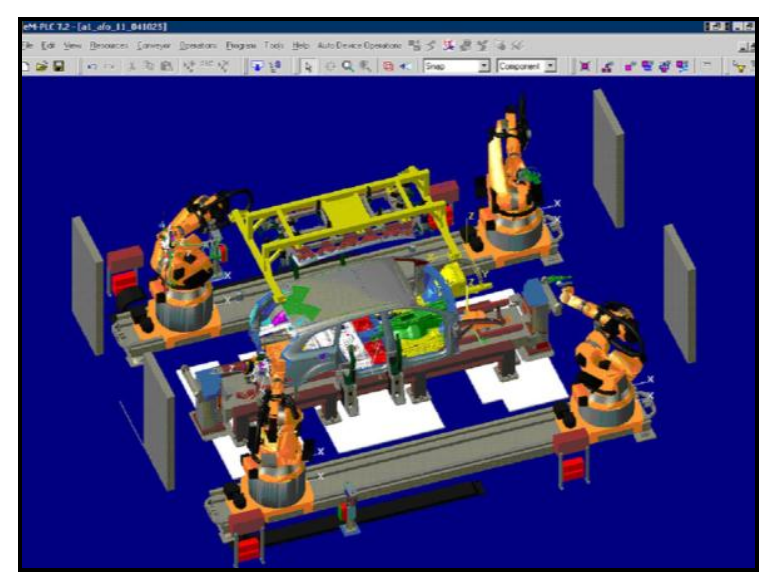

Obr 3: Pohl'ad na uživatel'ské rozhranie programu eM - Plant (riešenie pre automobilku Audi)

EM - Plant ponúka pre parametre modelov rôzne štatistiky: intervalovú štatistiku, celkovú štatistiku a momentálnu štatistiku.

Software QUEST (Queueing Event Simulation Tool) obr. 4 je systém ktorý dokáže simulovat' náhodným javom ovplyvnený tok materiálu. So systémom QUEST V3 sa dajú optimalizovat' výrobné a montážne postupy.

Dostupné základné stavebné bloky ako zásobníky, pracovné bunky $\mathrm{s}$ viacerými procesmi, zdroje, závesné dráhy, dopravné systémy, umožňujú rýchle modelovanie výrobného procesu. Extenzívna knižnica obsahuje vel'ký počet modelov a prevádzkových prostriedkov, takže modelovanie 3D - členov zaberá podl'a možnosti iba minimum času.

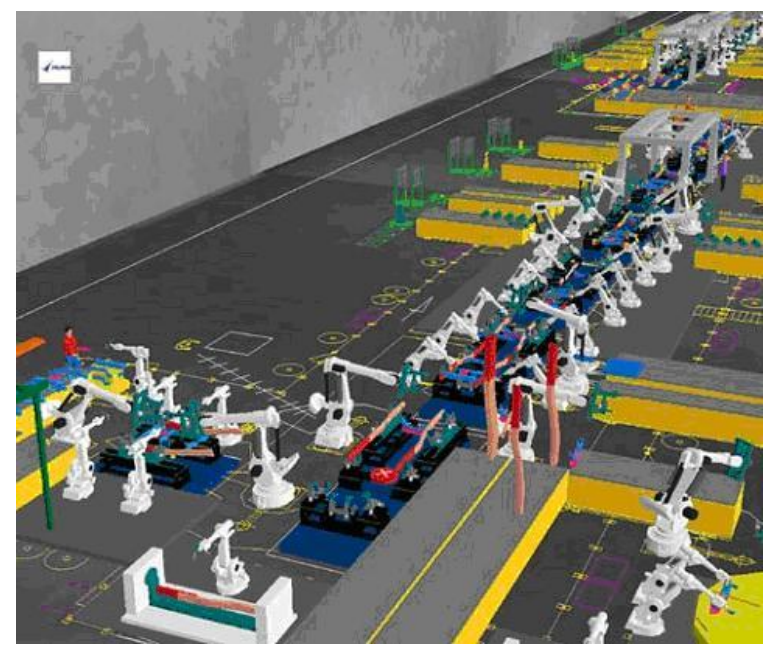

Obr 4: Pohl'ad na uživatel'ské rozhranie programu Quest
Kinematické pohyby robia simuláciu realistickou a obraznou a pre koncového užívatel'a zrozumitel'nou. Výsledky môžu byt' počas simulácie znázorňované graficky. Simulácia je v ktoromkol'vek okamihu interaktívne menitel’ná

\section{Závěr}

Nové zariadenia môžu byt' za pomoci simulácie preverené $\mathrm{z}$ hl'adiska priepustnosti, operačných časov, výkonových hraníc, poruchových vplyvov, požiadaviek na personál a iných plánovaných parametrov. $\mathrm{K}$ tomu môžu byt' vyhodnocované rôzne alternatívy a tieto potom navzájom porovnávané. $\mathrm{V}$ prípade, že by sa tento výskum robil priamo na hotovom zariadení zabralo by to vel'a času a zapríčinilo zvýšené náklady. Takto môžu byt' vd’aka simulačnému modelu zmeny l'ahko prevedené ešte vo fáze plánovania zariadenia.

Simulačný model slúži programátorom riadiacich automatov ako predloha na návrh a vývoj riadiaceho automatu, a má za následok rýchlejšie a bezchybné uvedenie do prevádzky. Prepojenie centrálneho riadiaceho počítača so simulačným modelom umožní jeho uvedenie do prevádzky ešte pred nasadením zariadenia.

Správanie sa počas nábehu môže byt' prehrávané podl'a rôznych scenárov. To je dôležité práve vtedy, ked' je uvádzanie do prevádzky prevádzané počas bežiacej prevádzky a je požadovaný bezproblémový prechod na nové zariadenie.

Obslužný personál môže byt' s pomocou modelu na nový systém zaškolený a cielene na konkrétne stavy zariadenia pripravený.

Predbežný test denného plánu nasadenia zariadenia upozorní na potreby pripravenosti personálu a prevádzkových prostriedkov, vzhl'adom na vyt’aženie zariadenia. Následne môže byt' denný plán $\mathrm{v}$ prípade potreby ešte včas upravený a opätovne preskúšaný.

Po preskúšaní modelu sa vykonávajú experimenty, $\mathrm{v}$ ktorých sa hl'adajú rôzne možnosti vylepšenia systému a overuje sa ich vplyv na modelovaný systém. Ako vidiet', simulácia nie je nástroj, ktorý umožní získat' priamo optimálne riešenie. Je to skôr podporný nástroj, ktorý pomáha projektantovi testovat' efekty svojich rozhodnutí na simulačnom modeli.

Pri výrobe karosérií Audi sa stáva „Virtuálna továreň “ teraz realitou: V mestách Ingolstadt a Neckarsulm je $\mathrm{v}$ automobilke Audi nasadený software od firmy Siemens a Technomatix. 
Spomínaná zmena sa priamo týka strategických oddelení odboru činnosti výroby karosérií [4].

Jedným z príkladov využitia simulácie v praxi vo firme Siemens je uvedenie zariadenia na prednastavenie prednej nápravy vozidla JEEP Grand Cherokee, pre automobilku Magna Steyr v Grazi v Rakúsku do prevádzky. Ide o zariadenie, ktoré je zaradené do existujúcej montážnej linky a jeho úlohou je presné nastavenie závesného bodu zvislého čapu na priečnom ramene prednej nápravy (obr. 5), čo v konečnom dôsledku zabezpečuje správny záklon a odklon kolesa na hotovom vozidle. Toto nastavenie sa deje pomocou dvoch pohonov umiestnených voči sebe v osiach otočených o 90 stupňov, čím sa zabezpečí možnost' nastavenia bodu $\mathrm{v}$ rovine $\mathrm{v}$ určitom rozsahu.

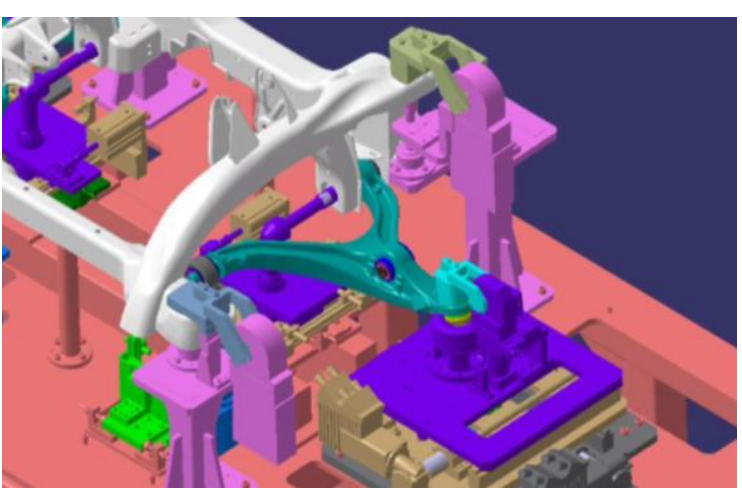

Obr 5: Príklad využitia simulácie

Z uvedených príkladov jednoznačne vyplýva potreba aplikovat' simuláciu výrobného procesu do výučby. V súčasnosti je na vysokých školách venovaný priestor na získanie znalostí z uvedených oblastí, avšak autori zdôrazňujú potrebu zväčšovania priestoru na prácu s jednotlivými softvérmi na získanie praktických znalostí, tvorivosti a samostatnosti študentov pri výučbe technických predmetov na vysokých a stredných školách technického zamerania.

Tento článok vznikol $\mathrm{V}$ rámci riešenia projektu: VEGA č. 1/0250/11.

\section{Literatura}

[1] Václav, Š. Valentovič, E.: OMA- Objective Method For Assembly. In: RaDMI 2006 : Proceedings on CD-ROM / nadát. International Conference. Budva, Montenegro, 13-17. Sept. 2006. - Trstenik : High Technical Mechanical
School of Trstenik, 2006. - ISBN 86-83803-21X. - S. 1-6

[2] Dringend gefordert - Intelligente und angepasste Automatisierung. MAV, 2002, č. 4, s. 44-45.

[3] Reiber, T., Jäkel, M.: Neue Konzepte für die Produktentwicklung. In. CAD-CAM REPORT, Nr. 7, 2004. str. $34-39$

[4] Schreiber, W.: Virtuelle Technik im Automobilbau. Transfer von Hochtechnologie. Volkswagen AG Konzernforschung Werkstofftechnik und Verfahren, 2004.

[5] Mareš, A., K. Senderská (2005). Modernization of manual assembly workstation. In: 5th. International conference - Research and development in mechanical industry RADMI 2005. Vrnjačka Banja (Serbia and Montenegro) High Technical Mechanical School of Trstenik,. str. 188 - 191. ISBN 86-83803-20-1

[6] Senderská, Katarína - Mareš, Albert FABIAN, Michal: Praktická aplikace ergonomických modulů CATIE při analýze ručního montážního pracoviště. In: IT CAD : Dvouměsíčník o CAD, počítačové grafice a CA.. technologiích. vol. 18, no. 2 (2008), p. 18-19. ISSN 1802-0011.

[7] Mareš, Albert et al. : Analýza pohybu rukou při ruční montáži pomocí datové rukavice. In: IT CAD: Dvouměsíčník o CAD, počítačové grafice a CA.. technologiích. vol. 18, no. 3 (2008), p. 2931. ISSN 1802-0011.

[8] Mareš, Albert - Senderská, Katarína: Capturing video of assembly operations for analysis purpose. In: RaDMI 2006 : 6th International Conference "Research and Development in Mechanical Industry" : Proceedings on CD-ROM : 13 - 17. September 2006, Budva, Montenegro. Trstenik : High Technical Mechanical School of Trstenik, 2006. 4 p. ISBN 86-83803-21-X.

Ing. Štefan Václav, PhD.,

Ing. Martin Benovič,

Slovenská Technická Univerzita v Bratislave, Materiálovo technologická fakulta so sídlom v Trnave, Ústav výrobných technológií, Katedra obrábania a montáže.

Paulínska 16, Trnava 917 24,

stefan.vaclav@stuba.sk, martin.benovič@stuba.sk, http://www.mtf.stuba.sk/ 